\title{
Edward Chamberlin: Monopolistic Competition And Pareto Optimality
}

Don Bellante (E-mail: dbellant@ coba.usf.edu), University of South Florida

\begin{abstract}
In treatments of Monopolistic Competition, Edward Chamberlin and Joan Robinson are usually credited with simultaneously and independently developing the theory of monopolistic or imperfect competition. While their contributions were indeed simultaneously developed, it is inappropriate to treat them as having duplicated each other's efforts. Yet it has become customary in many treatments to regard them as having done just that, and modern textbook treatments tend to mention the two as if they were interchangeable. In no respect were they less so than in their views of the welfare implications of monopolistic competition. But the passage of time seems to have resulted in a blurring of the distinction between them, and it has become a common practice to ascribe to monopolistic competition an incompatibility with Pareto optimality. An important point of focus of this paper is Chamberlin's response to the tendency to treat his analysis as indicating a market failure.
\end{abstract}

\section{Introduction}

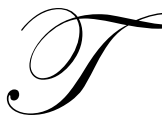

he decade of the 1930's gave rise to two "revolutions" in economic theory - the Keynesian Revolution in macroeconomics, and the Imperfect Competition Revolution in microeconomics. With development of the theory of imperfect competition, recognition is routinely jointly given to Edward Chamberlin (1933) and to Joan Robinson (1933). In modern price theory texts at all levels, and even in texts on the history of economic thought, the two contributions are often treated as more or less equivalent. Even where the differences between Chamberlain and Robinson have been acknowledged, they are often trivialized as is suggested by this quote from Paul Samuelson (1967) in a volume of essays in tribute to the influence of Chamberlin:

Indeed the time has come when we may permit ourselves to use the terms monopolistic competition and imperfect competition interchangeably, emancipating them from their first associations with the different conceptions of Chamberlin and Mrs. Robinson, using them as convenient names for the best current models of price theory.

Whether the discussion of imperfect or monopolistic competition centers on Chamberlin or Robinson, monopolistic competition generally is seen as a departure from the ideal of perfect competition that results in a loss of economic welfare - that is, a departure from Pareto optimality. And often, this departure is seen as a type of market failure in need of correction through government intervention. Certainly, this is how Joan Robinson viewed imperfect competition, as did the greatest number of their contemporaries who were congenial to their analysis. But it is a serious misinterpretation of Chamberlin's own position.

To Chamberlin, the product differentiation that characterizes imperfect competition is not welfare reducing, but welfare enhancing. Stated otherwise, society gets as much product diversity as it is willing to pay for. But even in his own time, his contribution was regarded as demonstrating the inefficiency of monopolistic competition - basically because the monopolistically competitive firm of his model does not operate at the low point of its long run average cost curve. Indeed, much of the rest of Chamberlin's life was spent arguing against this interpretation of his work, and differentiating his work from that of Robinson. But this episode has largely been lost to modern economists, as evidenced by the perusal of modern texts. 
The purpose of this paper will be to elaborate on this episode. Woven among the sections that follow are three objectives of this paper: Specifically, one objective of this paper is to outline the historical development of the influence and criticisms of Chamberlin. A second objective is to examine Chamberlin's attempts to distance himself from those who accepted his model but found welfare implications with which Chamberlin strongly disagreed. A third objective is to argue that the historical and still contemporary conclusion about the inefficiency of monopolistic competition is more of an indication of the weakness and limitation of static Paretian welfare economics than an indication of inefficiency due to less-than-perfectly elastic demand curves facing firms with differentiated products.

\section{Chamberlin vs. Robinson}

Despite the tendency to interpret Chamberlin and Robinson as having simultaneously developed essentially the same theory of monopolistic competition, historians of thought have not considered them to be equal giants in the field. A good example is in a comparison of the profiles of the two offered on the History of Thought web project of the New School. ${ }^{1}$ Whereas the quite laudatory remarks about Robinson are several pages in length, and the fact that she didn't receive a Nobel Prize is lamented, the discussion of Chamberlin is of a very different nature. The entire Chamberlin description is:

A Harvard economist whose career turned out to be disappointing after a promising start, Edward H. Chamberlin turned out to be a man of one idea: 'monopolistic competition', which he unveiled to the world in 1933, coincidentally with Joan Robinson's theory of imperfect competition. Chamberlin spent virtually the rest of his life on three tracks: (1) differentiating his theory from Robinson's; (2) defending his theory against the Chicago School and other critics; (3) puzzling why his theory had not brought on a revolution in microeconomics. All these narrow concerns are brought together in an unremarkable book of essays. ${ }^{2}$

It would of course be very difficult to argue against the judgment that Robinson's contributions to economics have greatly overshadowed those of Chamberlin. Her contributions have spanned the sub-fields of Keynesian Macro-economics, Cambridge Growth and Capital Theory, Distribution Theory, Marxian Economics, and Methodology. She was certainly the more colorful of the two characters. But it should be noted that the model of monopolistic competition that has survived in countless textbooks is that of Chamberlin, not Robinson's. This is the familiar graphical analysis in which the short run equilibrium of a monopolistically competitive firm potentially results in economic profit, but with free entry the long run equilibrium produces a tangency of the firm's demand curve with the downward-sloping portion of its long run average cost curve. ${ }^{3}$ The graphic depiction of long run equilibrium is reproduced in the appendix. This tangency results in only normal profit and in excess capacity.

As appropriately described in a leading History of Thought text (Landreth and Colander, 1994), "Chamberlin's work, though similar to Robinson's, was more far reaching. It attempted a thorough reconstruction of the theory of value." While Chamberlin viewed a competitive process as taking place within his model, hence the longrun dimension to his model, Robinson did not. In Robinson's perspective, there is no competing away of monopoly profits. Chamberlin developed an expansive analysis of product differentiation and of advertising whereas Robinson did not. What Robinson (1933, pp. 292-299) did do, that Chamberlin did not, was to interpret imperfect competition as by definition resulting in the exploitation of labor, i.e., the payment to labor of a wage less than its marginal product. In her analysis the fact that a firm faces an upward sloping supply curve of labor results in exploitation. Amazingly, Robinson points out that an upward slope may result from the supply being limited by geography. But this circumstance would normally improve the position of labor, so it is ironic that Robinson would label this situation as one of "exploitation", for which she recommended imposition of a legal or collectively bargained minimum as a cure. However, Chamberlin (1936) quite correctly demonstrated that in imperfect competition, all factors are in this sense "exploited" so that this particular definition of exploitation is a meaningless concept. As for Chamberlin being a "one idea" man, it should be noted that Chamberlin is the originator of the sub-field of Experimental Economics, for which the 2002 Nobel Prize was awarded to Vernon Smith for his modern development and advancement of the sub-field. In an interview with Reason, Smith indicates that his interest in developing the experimental approach to economics was motivated when he was a student of Chamberlin's and was subjected to his experiments. ${ }^{4}$ In fact, Chamberlin's "An Experimental Imperfect Market" (1948) is often cited as the seminal article in Experimental Eco- 
nomics by its current practitioners. Chamberlin's early use of the method has spawned further applications that have provided insights far removed from the topic of imperfect competition—voting models being one such example. ${ }^{5}$

Another sub-area of economics where Edward Chamberlin had immense influence is in what is commonly called Spatial Economics - the modern development of location theory in Regional Economics. ${ }^{6}$ It does not exaggerate to say that modern location theory for the most part simply extends Chamberlin's analysis of product differentiation in monopolistic competition to the case of differential location, wherein neither perfect competition nor pure monopoly models have any applicability or yield any insights. Chamberlin may rightfully be regarded as the inspiration of modern Industrial Organization Economics, with its emphasis on the conduct-structure-performance paradigm and its characterization of industry types.

Further, Chamberlin's two-curve model of demand forms the basis of Paul Sweezy's model of price rigidity under oligopoly - a model that for years pervaded textbooks from the principles level upward. Since the model no longer tends to be regarded as useful it perhaps cannot be counted as a long-lasting contribution for which Chamberlin is given credit by inspiration. But in the same vein, most of Robinson's contributions outside of imperfect competition, from Keynesian growth models to labor market monopsony, no longer enjoy much currency. So it is a debatable point as to who had the greater lasting influence.

After the 1933 edition, subsequent editions of Chamberlin's Theory of Monopolistic Competition addressed some of the criticisms of the first edition, and such responses continued through the eighth and final edition. Despite Chamberlin's attempts to engage Robinson in debate over their different perspectives, she largely chose to ignore him. Her means for doing so was to assert that when she and Chamberlin were talking about the same problems, they came to the same conclusions - and when they didn't come to the same conclusion it was because they were talking about different problems. Long after the first publication of their theories, Robinson (1960, p. 222) said: "I should like to take this opportunity of saying that I have never been able to grasp the nature of the distinction between imperfect and monopolistic competition to which Professor Chamberlin attaches so much importance." 7 What was not different between them was their assessment of the inadequacy and inapplicability of the model of perfect competition. Chamberlin saw virtually all markets as having elements of monopoly and competition, but did not see this condition as a market failure. Robinson, on the contrary, tended to see every departure from perfect competition as a nail in the intellectual coffin of free market capitalism.

\section{Chamberlin's Critics}

While Chamberlin had many critics in his time, the technical criticisms of his model are not the major concern of this paper. While some are fairly straightforward, others are quite complex and an elaboration of them is beyond the scope of this discussion. To briefly summarize, critics often found the greatest difficulty in accepting either or both of (a) the concept of product differentiation combined with free entry or (b) the implication of the "tangency conclusion" that monopolistically competitive firms will have excess capacity even in long run equilibrium. Nicholas Kaldor's well-known criticism in large measure involved both. More directly, Kaldor $(1935,1938)$ had difficulty seeing any difference between monopolistic competition, as exposited by Chamberlin, and perfect competition. $^{8}$ His difficulty is connected to the free entry condition with which Chamberlin characterized monopolistic competition. With free entry, Kaldor reasoned, rival firms could enter not only with close substitutes but with identical products. Apparently Kaldor, like most economists of the day, could not break themselves away from the Marshallian mode of thinking that saw everything traded as homogeneous commodities without the characteristics of brand loyalty, quality differentials, heterogeneous consumer perceptions and idiosyncratic services. In this mode, an industry is clearly defined. In contrast, Chamberlin's perception was more in the mode of modern demand theory that sees "commodities" as inputs into the production of "goods". It is the goods that yield utility, and the distinction between commodities and goods is the basis for the approach of Kevin Lancaster (1971) with regard to consumer behavior and Gary Becker (1965) with regard to the allocation of time. In this framework as well as Chamberlin's, the concept of "industry" loses its precision.

Of course to the extent that analysts had difficulty seeing a difference between monopolistic and perfect competition they would by definition have difficulty accepting the excess capacity conclusion. But the reluctance of 
many economists to accept the excess capacity conclusion was more widespread. The excess capacity conclusion follows from the geometry of Chamberlin, and little in the way of logic. It is dependent on the firms that compete against each other having identical cost structures. But many critics have pointed out that there is an inconsistency between the assumption of heterogeneous products and uniform cost functions. Others have argued that product differentiation needn't lead to production on the downward slope of a firm's cost curve. One textbook that succinctly summarized this perspective was written by Donald Dewey (1975, p. 171):

Consider the case of, say, bubble gum. Peppermint-flavored sticks and cherry-flavored sticks are the same product except for the flavoring imparted to the basic gum at some stage in the production process. Both types are produced with the same fixed investment - machines, skilled workers, warehouses, etc. Expenditures on flavoring fluids to differentiate gum are variable costs. There is no reason to believe that gum will be produced where average total cost is falling simply because the industry produces different flavors. ...It follows that if the cost of differentiating a commodity from its close substitutes is to constitute a barrier to efficient production, this cost must be a fixed cost. The technology used to manufacture an air-cooled automobile engine is from that used to produce a water-cooled automobile engine. Each type requires its own specialized tools and dies. Hence if the economy produced both types of engine, it is possible that each type will be produced in a plant where average total cost is falling. Can we say that the existence of two such plants ...is evidence of "excess capacity"? Obviously not. ...[P]roviding there is no cheaper way to produce the particular mix of ...engines that is offered on the market, there is no excess capacity.

The excess capacity via tangency conclusion can be disputed on even simpler grounds. For one, in the real world empirically measured costs seem to have a wide range of relatively flat marginal and total cost curves, unlike the typical textbook depictions. As a consequence, the tangency-induced excess capacity, while not moot, is of little practical significance. Further, as Murray Rothbard (1993, p. 643-4) has pointed out, the tangency solution rests on the assumption of continuous demand and cost functions. These are convenient for mathematical derivation, but at odds with the real world that is characterized by discrete functions. Even more fundamentally, Roy Harrod (1952, p.149), in anticipation of a rational expectations argument, pointed out the irrationality assumed in alleging that a firm's managers, knowing that market conditions will force them to produce one level of output as dictated by the tangency solution, would then choose to build a plant of a size that is optimal for a higher level of production.

More recent criticisms of the excess capacity conclusion are more complex. The "contestable markets" literature spawned by William Baumol and colleagues essentially concludes that free entry and exit is sufficient to negate excess capacity in less that perfectly competitive firms. ${ }^{9}$ It is easy to see a connection between the concept of "contestable markets" and that of "Workable Competition" fostered much earlier by John Maurice Clark (1940). One of the leading Institutional Economists of the $20^{\text {th }}$ century, Clark took the position that in many if not most industries, potential rivalry would be sufficient to reduce the difference between the efficiency of monopolistic vs. perfect competition (including the matter of capacity use) to such a small matter of degree that public policy need not address the difference. Moreover, Clark was in agreement with Chamberlin that the model of perfect competition, besides having little connection with the real world, should not be the norm that should form the basis for public policy - particularly antitrust policy (Clark, 1957, 158-156). The use of the model of perfect competition as an ideal structure toward which public policy should be aimed is further discussed below.

Further, Greenhut, Norman and Hung (1987, chapter 19) have demonstrated that under conditions of uncertainty (and with the existence of a return to entrepreneurial uncertainty) excess capacity is not possible in equilibrium. ${ }^{10}$ The emphasis that his contemporaries put on the tangency solution was a source of irritation to Chamberlin. Ironically, it was and still is the most prominent feature that the economics profession has taken from Chamberlin's work. Despite the attractiveness of this feature to many in the profession, Chamberlin in later editions and in other forums put this irritation in print. ${ }^{11}$ One difficulty that many in the profession had with monopolistic competition as adding anything more than descriptive accuracy to the understanding of markets had to do with the definition of a market. Chamberlin did not talk of market equilibria, but rather of group equilibria. The group was a collection of firms producing non-identical but closely related products. By "closely related" Chamberlin meant having high elasticities of substitution, but such elasticity is a relative matter. As Chamberlin himself pointed out, all goods are substitutes for one another, varying only by degree. But this fact makes the dividing line of the group indeterminate. 
In short, acceptance of Chamberlin's theory would destroy the (seemingly) clear conception of a market or industry embedded in economic theory by Marshall. Moreover, in doing so monopolistic competition is rendered incompatible with general equilibrium theory, to which the profession is enamored. To many, this inconsistency substantially limited the value of Chamberlin's contribution. To others this inconsistency was merely a fact that had to be lived with, and simply limited the scope of applicability of the theory to partial equilibrium problems, e.g., Robert Triffin (1940).

While there unquestionably were significant technical problems with the theory of imperfect competition, it must be said that Chamberlin's inability to foster the complete transformation of microeconomic theory he envisioned does not so much stem from these technical problems. Criticism from the Chicago School, though late in materializing, remains the most influential as it went to the heart of the methodological foundation of the concept of monopolistic competition. In particular, the methodological positivist approach of Milton Friedman (1953) takes as one of its central propositions that a theory must explain a wide range of phenomena, and this necessitates the establishment of inherently unrealistic assumptions. But it is not the realism or lack of it in a theory's assumptions by which that theory should be judged, but rather by the accuracy of its explanations or predictions. By this standard, Friedman and methodologically like-minded economists have deemed Chamberlin's model of monopolistic competition to be a failure, adding nothing to what is understood by reference to the polar models of perfect competition and pure monopoly. On monopolistic competition specifically, Friedman says (on pages 15 and 39):

The development of this analysis was explicitly motivated, and its wide acceptance and approval largely explained, by the belief that the assumptions of "perfect competition" or "perfect monopoly" said to underlie neoclassical economic theory are a false image of reality. And this belief was itself based almost entirely on the directly perceived descriptive inaccuracy of the assumptions rather than on any recognized contradiction of the predictions derived from neoclassical economic theory. ...

The theory of monopolistic competition offers no tools for the analysis of an industry and so no stopping place between the firm at one extreme and general equilibrium at the other. It is therefore incompetent to contribute to the analysis of a host of important problems: the one extreme is too narrow to be of great interest; the other, too broad to permit meaningful generalizations.

The methodological positivism of the Chicago school remains the conventional doctrine of the neoclassical economics mainstream, although most in that mainstream of course do not totally dismiss Chamberlin's contribution. ${ }^{12}$ But among many associated with the Chicago School, the rejection remains rather complete. ${ }^{13}$ For example the once popular price theory texts of Friedman (1976) and George Stigler (1987) make no mention of either monopolistic competition or Edward Chamberlin.

\section{Monopolistic Competition And Economic Welfare}

Whatever one's conclusions about the various critiques of Chamberlin's contribution by his "enemies", the more baffling to Chamberlin must have been the assessments by his "friends". By "friends" we mean those economists who accepted his model along with the excess capacity conclusion, and from it drew the now standard conclusion of the inefficiency of monopolistic competition. That Edward Chamberlin objected to the welfare implications inferred by his followers is a fact that seems to be lost to history. Modern textbooks either treat the excess capacity conclusion as evidence in itself of welfare loss, (i.e., a violation of the conditions for Pareto optimality) or allow for the possibility that against the inefficiency in production must be weighed the gain to consumers that in some circumstances may accrue from product variety. But this latter effect is almost never attributed to Chamberlin himself. $^{14}$ Yet Chamberlin expressed his dissent in print repeatedly, including in subsequent editions of Monopolistic Competition, but in no place more emphatically than at a session of an annual meeting of the American Economics Association (Chamberlin, 1950). ${ }^{15}$ On page 85 , he states:

I must again lament the widespread misunderstanding of the subject [of monopolistic competition]; so that what has been "conquered" [in terms of the widespread acceptance of the model] appears to be something quite contrary to the theory, at least as I understand it. ...The supremacy of pure competition with its corollary of prices 
equal to marginal costs as the economic welfare ideal is well known. ... What is perhaps not so well appreciated is how explicitly monopolistic competition has been interpreted as merely indicating the nature of the departures from the ideal which need to be corrected. ... The main point I want to make is that the welfare ideal itself (as well as the description of reality) involves a blend of monopoly and competition and is therefore correctly described as one of monopolistic competition.

Of course, the tangency solution that is characteristic of the model of monopolistic competition is the facet of Chamberlin's model that leads to the excess capacity and consequent welfare loss conclusion to which Chamberlin objects. As already mentioned, Chamberlin expressed irritation about what he regarded as excess emphasis on excess capacity. But he never disavowed excess capacity as a characteristic of monopolistic competition. Obviously then, his reluctance to accept the conclusion that a welfare loss necessarily followed from the existence of monopolistic competition was not based on a denial of excess capacity. Before continuing with Chamberlin's critique of what we have called his "friends" however, it should be pointed out that downward-sloping demand curves result in general excess capacity (that is, excess capacity for all firms in a Chamberlinian group) only when the cost curves of all firms in the group are identical. Otherwise, only the highest cost firm necessarily will have excess capacity. Other firms may have excess capacity, or "insufficient" capacity - no generalization is possible. Importantly, even under perfect competition, as long as firms do not have identical cost curves, the usual conclusion of all firms in long run equilibrium operating at ideal (minimum cost) capacity does not hold. ${ }^{16}$ The welfare implication is a negative one - that is, there is no basis for assuming that monopolistic competition is less efficient than perfect competition. ${ }^{17}$ Though this is not the approach taken by Chamberlin, it arrives at the same conclusion - perfect competition is not the welfare ideal against which the real world of monopolistic competition should be compared and not the ideal toward which public policy should aim.

Returning to Chamberlin (1950, p. 86), he describes human beings as by their nature diverse, as well as spatially separated, and these facts in themselves should lead to entrepreneurs appealing to these diverse demands with heterogeneous products. And if diversity is what consumers want, and consumer wants supposedly form the basis of welfare, then a correct measure of welfare would incorporate this truth into construction of the welfare ideal. Chamberlin then (p. 87) contrasts this perspective to the perspective one can deduce from Joan Robinson and others, wherein product heterogeneity is an artificial contrivance of producers that works to the detriment of consumers. Chamberlin goes on to attack (p. 88) the notion that product differentiation is attributable to imperfect knowledge, "as though the individuality of particular products could be dismissed as an optical illusion based on ignorance - a purely psychic phenomenon." According to Chamberlin, there is as much reason to believe that perfect information would result in stronger recognition of the differences in products as in their similarities, and that this would manifest itself in the market by the demand curves for individual producers becoming less, not more, elastic. In a similar vein, Chamberlin then minimizes the criticism of product heterogeneity as being the result of irrational preferences. And on page 89, he responds to the tendency to view preferences for differentiated products as irrational because they are influenced by advertising, adding: "The general condemnation of advertising as a waste surely has its primary explanation in the irrelevancy that it could not exist under the perfectly competitive ideal." Indeed, Kenneth Boulding in his very successful Economic Analysis (1966) the $1^{\text {st }}$ edition of which was published in 1941, after condemning most advertising as wasteful, says just that in a section headed "No Competitive Advertising under Perfect Competition". Also on page 89, Chamberlin argues that while it is true that in monopolistic competition firms do not operate on the low point of their average cost curves, and in this sense might be "inefficient" (as it is by definition in welfare economics), product differentiation can not be said to reduce economic welfare unless it can be shown that the loss of efficiency in this sense is somehow greater than the gain in consumer utility. He argued that the inability of welfare economics to incorporate this and other aspects of monopolistic competition indicates the inadequacy of modern welfare economics, not of the theory of monopolistic competition. Chamberlin concludes (p. 92) as follows:

Thus, wherever there is a demand for diversity of product, pure competition turns out to be not the ideal but a departure from it. Marginal cost pricing no longer holds as a principle of welfare economics ...nor is the minimum point on the cost curve for the firm to be associated with the ideal. Selling costs may no longer be excluded from the problem or dismissed as an obvious waste; yet the impossibility of discovering from the standard welfare techniques what is the socially ideal expenditure on selling suggests that the techniques are unduly narrow. ... What 
has been called the "new welfare economics," instead of being on a "secure basis" ... has quite misconceived a whole set of major problems. It is badly in need of a general overhauling.

\section{Conclusion}

Nowhere does Chamberlin distinctly state that the degree of product diversity generated in the market would be provably ideal (Pareto optimal). His point was that general equilibrium theory and welfare economics, as they stood half a century ago, could not shed any light on the matter. But if his model of monopolistic competition were incompatible with general equilibrium and welfare economics, it not only was because of the limitations and inadequacies of welfare economics, but also the false notion of the existence of a Marshallian industry demand curve that persists today. The latter persists because it tells a neat and formal story that fits so well into the general equilibrium construct that economists so admire, irrespective of the fact that it doesn't exist in a real world of product differentiation by degree.

A half-century later, the inadequacy of which Chamberlin complained remains. Graduate students in Economics are taught all of the mechanics of welfare statics, and perfect competition is still presented as the ideal. The various ways in which the real world departs from this ideal are catalogued, e.g., externalities and public goods, monopoly, and - in more advanced discussions - opportunism, moral hazard, asymmetric information etc. All of these exercises provide valuable insights. Arguably, there is no better pedagogical device for making students aware of the complexity of the interrelationships that exist in the real world, but which are necessarily ignored in partial equilibrium analysis. But seldom in such expositions is the technique of welfare economics itself called into question and its severe limitations examined. The one exception has to do with the fact that the technique cannot identify any particular wealth distribution as a welfare ideal. Arguably, this is the least consequential inadequacy of welfare economics but it stems from the disconnect in welfare theory (but not in the real world) between exchange and production on the one hand and the personal distribution of wealth on the other. Moreover, there has been little in the way of attempts to reconstruct Paretian welfare economics in such a way as to recognize and incorporate the utility producing aspects of product heterogeneity. It is noteworthy that the classics on general equilibrium and welfare have tended either to simply ignore product heterogeneity (e.g., Quirk and Saposnik, 1968), or discuss it tangentially (e.g., Scitovsky, 1951). The only differentiation that Kuenne (1963) entertained is with regard to spatial differentiation. One exception that nonetheless does not seem to have influenced the way economists have treated heterogeneity is Lancaster (1975). In a model based on his influential "characteristics approach" to consumer demand theory (1971), Lancaster concludes that (a) there is a socially optimal degree of product differentiation; and (b) it is not possible in the real world to identify what would be this optimal degree $\left(1975\right.$, p. 584). ${ }^{18}$

It is of course not only the Chamberlinian perspective that is a square peg that can't be fit into the round hole of modern welfare economics with its static ideal of perfect competition-so too is the perspective of Joseph Schumpeter (1942). Schumpeter always regarded perfect competition as an exceedingly imperfect ideal that, if it could be attained, would be antithetical to the entire process of innovation and economic progress. Schumpeter died before completing his massive History of Economic Analysis (1954). Despite a dozen very brief references to Chamberlin, Schumpeter, though he intended to do so, never got around to giving a complete assessment of the Chamberlin model. Chamberlin (1951), however, considered his perspective completely compatible with that of Schumpeter. One contemporary of theirs who also saw them as compatible, and who also shared Chamberlin's perspective on the implications of product diversity for consumer welfare, was Alex Hunter (1955). But on the latter concern, he appears to have been very much in the minority. Both Schumpeter and Chamberlin dealt with the dynamics of market processes, which are not easily treated in formal equilibrium models. However, Chamberlin is today given nowhere near the recognition for doing so as Schumpeter. It is an interesting exercise to speculate as to why this is so. Perhaps it is because Schumpeter never attempted to formalize his story, whereas Chamberlin not only did attempt to formalize his story but did so in the only way economists of his day formalized anything - that is, in static equilibrium terms. In an interview, Brian Loasby has attested to the fact that Chamberlin was primarily concerned with market processes, and viewed the activities of monopolistic competitors as part of the discovery process that today is the focus of modern Austrian School economists. ${ }^{19}$ Thus, a reinterpretation and reevaluation of Chamberlin may well be in order. In light of all that economists have learned in the last half-century, such a reevaluation may well raise the esteem in which Chamberlin is held. 


\section{Endnotes}

1. See "Edward H. Chamberlin, 1899-1967" http://cepa.newschool.edu/het/profiles/chamberlin.htm and "Joan Violet Robinson, 1903-1983" http://cepa.newschool.edu/het/profiles/robinson.htm.

2. The reference to the "unremarkable book" is Chamberlin (1957).

3. It should be noted, however, that Chamberlin did not employ the terms "Marginal Revenue" and "Marginal Cost" that are abbreviated in the graph shown in the appendix. The use of these terms originates with Robinson.

4. This interview is available online at: http://www.reason.com/0212/fe.ml.the.shtml. Interestingly, Smith attributes his attraction to the experimental method to dissatisfaction with Chamberlin's conclusions.

5. See the Southern Economic Association 2002 Presidential Address of Charles Holt (2003).

6. Chamberlin recognized the locational dimension of product differentiation and his approach was greatly expanded by specialists in Regional Economics. An excellent example of this approach to location theory is Greenhut, Norman, and Hung (1987). These authors label the location theory of Lösch (1954) the undoubtedly seminal and still standard work, while at the same time asserting a "strong intellectual debt Lösch owed to Chamberlin (1933) in the development of his ideas" (p. 263).

7. The quote is from a reprinted statement Robinson originally made in an article entitled " 'Imperfect Competition' Revisited" in the Economic Journal in 1953.

8. Kaldor (1934) was critical of Robinson's conception of imperfect competition as well.

9. $\quad$ See Baumol (1982) and Baumol, Panzar and Willig (1982).

10. Once again, J. M. Clark (1940) over sixty years ago informally argued theories that would later be formalized. In this case, he contended that uncertainty would eliminate the excess capacity conclusion of monopolistic competition. His argument, however, was confined to uncertainty of product demand.

11. A comprehensive treatment of the transformation of Chamberlin's analysis through subsequent editions, and particularly his responses to critics of his 1933 edition, is given in Romney Robinson (1971).

12. In light of Friedman's statement that monopolistic competition "offers no tools for the analysis of an industry" it should be mentioned that Chamberlin had pretty much given up on the idea of a group equilibrium by the time of his Towards of More General Theory of Value (1957).

13. A more complete elaboration of the Chicago School position on monopolistic competition is Stigler (1949). While the literature on the debates between critics and proponents of monopolistic competition is too extensive to review here, one can get the flavor of the debate by reading two assessments, one pro (Bishop, 1964) and one con (Machlup, 1937) reprinted in the same volume (Kamerschen, 1967).

14. One History of Thought textbook that briefly but correctly does note Chamberlin's perspective on product differentiation and economic welfare is Ekelund and Hébert (1997, pp. 443-450).

15. Romney Robinson (1971) thoroughly analyzes the changes in Chamberlin's Monopolistic Competition over various editions.

16. No doubt some economists see identical cost curves not as a heuristic assumption but a domain assumption, that is, part of the definition of perfect competition. To avoid a semantic argument, by perfect competition we mean in this specific case a market in which firms demand curves are perfectly elastic, without regard to cost conditions. For a discussion of the distinction between the two types of assumptions, see Musgrave (1981) as well as Holcombe (1989, chapter 2).

17. An elaboration involving graphical analysis of the case of non-identical cost curves for both perfect and monopolistic competition is given in Call and Holahan (1980, chapters 8 and 12).

18. Interestingly, Lancaster was one of the many economists who thought that Chamberlin embarrassed himself in his disagreement with Robinson, describing Chamberlin's effort as an "often pathetic struggle to retain sole title to imperfect competition". (1975, p. 567).

19. An Interview with Brian J. Loasby by Nicolai Foss (1997). That Loasby regards Chamberlin's work so much more highly than Robinson's is noteworthy, as Loasby was a student of Joan Robinson's at Cambridge. 


\section{References}

1. Baumol, William, 1982. "An Uprising in the Theory of Industrial Structure", American Economic Review, 72(1), 1-15.

2. _ J. C. Panzar and Robert Willig, 1982. Contestable Markets and the Theory of Industrial Structure. San Diego: Harcourt Brace Jovanovich.

3. Becker, Gary, 1965. "A Theory of the Allocation of Time", Economic Journal, 75(299), 493-517.

4. Bishop, Robert, 1964. "The Theory of Monopolistic Competition after Thirty Years: The Impact on General Theory", American Economic Review, 54(3), 33-43.

5. Boulding, Kenneth, 1966. Economic Analysis, Volume I: Microeconomics. New York: Harper \& Row.

6. Chamberlin, Edward, 1933. Theory of Monopolistic Competition. Cambridge, MA: Harvard University Press.

7. 1936. "Monopolistic Competition and the Productivity Theory of Distribution", Explorations in Economics. New York: McGraw-Hill, 237-249. Reprinted in William Fellner and Bernard F. Haley, editors, 1951. Readings in the Theory of Income Distribution. Philadelphia: Blakiston, 143-157.

8. _ 1948. "An Experimental Imperfect Market", Journal of Political Economy, 56(2), 95-108.

9. 1 1950. "Product Heterogeneity and Public Policy", American Economic Review, Papers and $\overline{\text { Proceedings }}, 40(2), 85-92$.

10. _ 1951. "The Impact of Recent Monopoly Theory on the Schumpeterian System", Review of Economics and Statistics, 33(2), 133-138.

11. 1957. Towards of More General Theory of Value. New York: Oxford University Press.

12. Call, Steven and William Holahan, 1980. Microeconomics. Belmont, CA: Wadsworth Publishing.

13. Clark, John Maurice, 1940. "Toward a Concept of Workable Competition", American Economic Review, 30(2), 241-256.

14. _ 1957. Economic Institutions and Human Welfare. New York: Alfred A. Knopf.

15. Dewey, Donald, 1975. Microeconomics: The Analysis of Prices and Markets. New York: Oxford University Press.

16. Ekelund, Robert and Robert Hébert, 1997. A History of Economic Theory and Method. New York: McGraw-Hill.

17. Foss, Nicolai, 1997. An Interview with Brian J. Loasby. Working Paper 97-9, Department of Industrial Economics and Strategy. Copenhagen: Copenhagen Business School.

18. Friedman, Milton, 1953. Essays in Positive Economics. Chicago: University of Chicago.

19. 1976. Price Theory. Chicago: Aldine Publishing.

20. Greenhut, Melvin, George Norman and Chao-Shun Hung, 1987. The Economics of Imperfect Competition: A Spatial Approach. Cambridge: Cambridge University Press.

21. Harrod, Roy, 1952. Economic Essays. New York: Harcourt Brace.

22. Holcombe, Randall, 1989. Economic Models and Methodology. Westport, CT: Greenwood Press.

23. Holt, Charles, 2003. "Economic Science: An Experimental Approach to Teaching and Research", Southern Economic Journal, 69(4), 755-771.

24. Hunter, Alex, 1955. "Product Differentiation and Welfare Economics", Quarterly Journal of Economics, 69(4), 533-552.

25. Kaldor, Nicholas, 1934. “Mrs. Robinson's ‘Economics of Imperfect Competition' “, Economica. New Series 1(3), 335-341.

26.

27. , 1935. "Market Imperfection and Excess Capacity", Economica. New Series 2(5), 33-50.

nal of Economics. 52(3), 513-538.

28. Kamerschen, David, 1967. Readings in Microeconomics. Cleveland: World Publishing.

29. Kuenne, Robert, 1963. The Theory of General Economic Equilibrium. Princeton, NJ: Princeton University Press.

30. Lancaster, Kevin, 1971. Consumer Demand: A New Approach. New York: Columbia University Press.

31. , 1975. "Socially Optimal Product Differentiation", American Economic Review. 65(4), 567585. 
32. Landreth, Harry, and David Colander, 1994. History of Economic Thought. (4 ${ }^{\text {th }}$ ed.) Boston: Houghton Mifflin.

33. Lösch, August, 1954. The Economics of Location. New Haven: Yale University Press.

34. Machlup, Fritz, 1937. "Monopoly and Competition: A Classification of Market Positions", American Economic Review. 38(4), 445-451.

35. Musgrave, Alan, 1981. " 'Unreal Assumptions' in Economic Theory: The F-Twist Untwisted”, Kyklos, 34(3), 377-387.

36. Quirk, James and Rubin Saposnik, 1968. Introduction to General Equilibrium Theory and Welfare Economics. New York: McGraw-Hill.

37. Robinson, Joan, 1933. The Economics of Imperfect Competition. London: Macmillan.

38. 1960. Collected Economic Papers, Volume 2. Oxford: Basil Blackwell \& Mott.

39. Robinson, Romney, 1971. Edward H. Chamberlin. New York: Columbia University Press.

40. Rothbard, Murray, 1993. Man, Economy, and State. ( $3^{\text {rd }}$ ed.) Auburn, AL: Ludwig von Mises Institute.

41. Samuelson, Paul, 1967. "The Monopolistic Competition Revolution" in Robert E. Kuenne, editor, Monopolistic Competition Theory: Studies in Impact. New York: John Wiley \& Sons.

42. Schumpeter, Joseph, 1942. Capitalism, Socialism and Democracy. New York: Harper \& Brothers.

43. 1954. History of Economic Analysis. New York: Oxford University Press.

44. Scitovsky, Tibor, 1951. Welfare and Competition. Chicago: Richard D. Irwin.

45. Stigler, George, 1949. "Monopolistic Competition in Retrospect" (12-24) in Five Lectures on Economic Problems. London: Macmillan

46. 1987. The Theory of Price. ( $4^{\text {th }}$ ed.) London: Macmillan Publishing.

47. Sweezy, Paul, 1939. "Demand under Conditions of Oligopoly", Journal of Political Economy, 47(4), 6873.

48. Triffen, Robert, 1940. Monopolistic Competition and General Equilibrium Theory. Cambridge: Harvard University Press.

\section{Appendix}

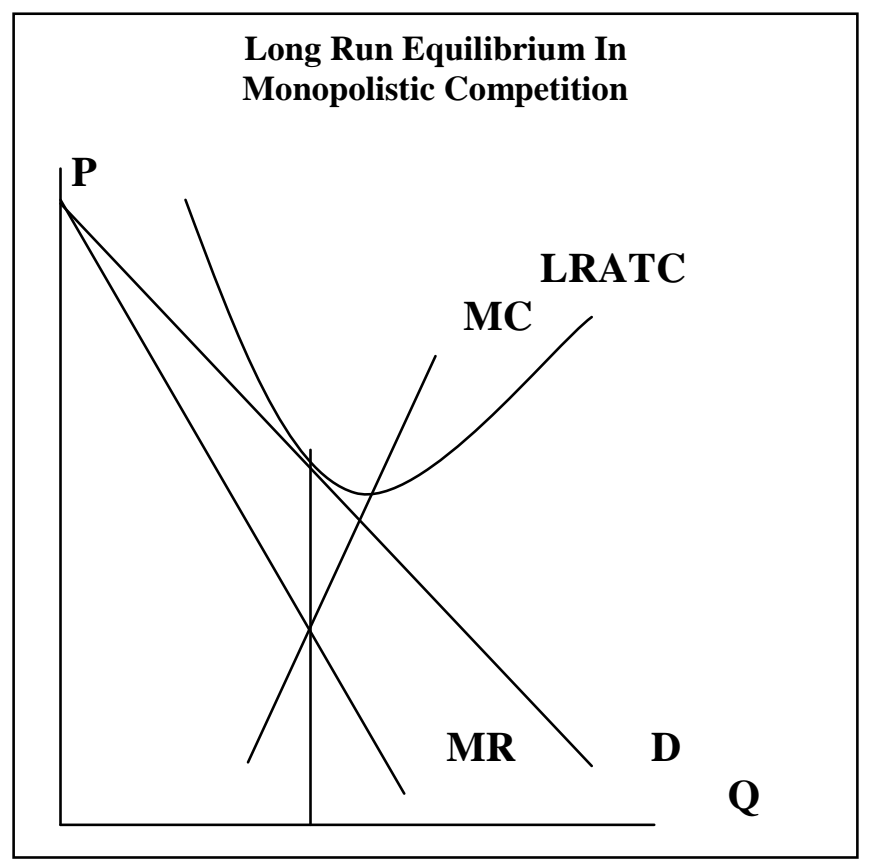




\section{Do Not Print This Page!!!}

\section{Endnotes}

${ }^{1}$ See "Edward H. Chamberlin, 1899-1967" http://cepa.newschool.edu/het/profiles/chamberlin.htm and "Joan Violet Robinson, 1903-1983" http://cepa.newschool.edu/het/profiles/robinson.htm.

${ }^{2}$ The reference to the "unremarkable book" is Chamberlin (1957).

${ }^{3}$ It should be noted, however, that Chamberlin did not employ the terms "Marginal Revenue" and "Marginal Cost" that are abbreviated in the graph shown in the appendix. The use of these terms originates with Robinson.

${ }^{4}$ This interview is available online at: http://www.reason.com/0212/fe.ml.the.shtml. Interestingly, Smith attributes his attraction to the experimental method to dissatisfaction with Chamberlin's conclusions.

${ }^{5}$ See the Southern Economic Association 2002 Presidential Address of Charles Holt (2003).

${ }^{6}$ Chamberlin recognized the locational dimension of product differentiation and his approach was greatly expanded by specialists in Regional Economics. An excellent example of this approach to location theory is Greenhut, Norman, and Hung (1987). These authors label the location theory of Lösch (1954) the undoubtedly seminal and still standard work, while at the same time asserting a "strong intellectual debt Lösch owed to Chamberlin (1933) in the development of his ideas" (p. 263).

${ }^{7}$ The quote is from a reprinted statement Robinson originally made in an article entitled "'Imperfect Competition' Revisited" in the Economic Journal in 1953.

${ }^{8}$ Kaldor (1934) was critical of Robinson's conception of imperfect competition as well.

${ }^{9}$ See Baumol (1982) and Baumol, Panzar and Willig (1982)

${ }^{10}$ Once again, J. M. Clark (1940) over sixty years ago informally argued theories that would later be formalized. In this case, he contended that uncertainty would eliminate the excess capacity conclusion of monopolistic competition. His argument, however, was confined to uncertainty of product demand.

${ }^{11}$ A comprehensive treatment of the transformation of Chamberlin's analysis through subsequent editions, and particularly his responses to critics of his 1933 edition, is given in Romney Robinson (1971).

${ }^{12}$ In light of Friedman's statement that monopolistic competition "offers no tools for the analysis of an industry" it should be mentioned that Chamberlin had pretty much given up on the idea of a group equilibrium by the time of his Towards of More General Theory of Value (1957).

${ }^{13}$ A more complete elaboration of the Chicago School position on monopolistic competition is Stigler (1949). While the literature on the debates between critics and proponents of monopolistic competition is too extensive to review here, one can get the flavor of the debate by reading two assessments, one pro (Bishop, 1964) and one con (Machlup, 1937) reprinted in the same volume (Kamerschen, 1967).

${ }^{14}$ One History of Though textbook that briefly but correctly does note Chamberlin's perspective on product differentiation and economic welfare is Ekelund and Hébert (1997, pp. 443-450).

${ }^{15}$ Romney Robinson (1971) thoroughly analyzes the changes in Chamberlin's Monopolistic Competition over various editions.

${ }^{16}$ No doubt some economists see identical cost curves not as a heuristic assumption but a domain assumption, that is, part of the definition of perfect competition. To avoid a semantic argument, by perfect competition we mean in this specific case a market in which firms demand curves are perfectly elastic, without regard to cost conditions. For a discussion of the distinction between the two types of assumptions, see Musgrave (1981) as well as Holcombe (1989, chapter 2).

${ }^{17}$ An elaboration involving graphical analysis of the case of non-identical cost curves for both perfect and monopolistic competition is given in Call and Holahan (1980, chapters 8 and 12). 
${ }^{18}$ Interestingly, Lancaster was one of the many economists who thought that Chamberlin embarrassed himself in his disagreement with Robinson, describing Chamberlin's effort as an "often pathetic struggle to retain sole title to imperfect competition". (1975, p. 567).

${ }^{19}$ See An Interview with Brian J. Loasby by Nicolai Foss (1997). That Loasby regards Chamberlin's work so much more highly than Robinson's is noteworthy, as Loasby was a student of Joan Robinson's at Cambridge. 